\title{
Molecular analysis of lipoid proteinosis: identification of a novel nonsense mutation in the ECM1 gene in a Pakistani family
}

\author{
Muhammad Nasir ${ }^{1}$, Amir Latif ${ }^{2}$, Muhammad Ajmal $^{1}$, Reem Qamar $^{3}$, Muhammad Naeem $^{3 *}$ and Abdul Hameed
}

\begin{abstract}
Lipoid proteinosis is a rare autosomal recessive disease characterized by cutaneous and mucosal lesions and hoarseness appearing in early childhood that is caused by homozygous or compound heterozygous mutations in the ECM1 gene located on chromosome 1q21. The aim of the study was to investigate the molecular genetic defect underlying lipoid proteinosis in a consanguineous Pakistani family.

Methods: Genotyping of seven members of the family was performed by amplifying microsatellite markers, tightly linked to the ECM1 gene. To screen for mutations in the ECM1 gene, all of its exons and splice junctions were PCR amplified from genomic DNA and analyzed by SSCP and sequenced directly in an ABI 3130 genetic analyzer.

Results: The results revealed linkage of the LP family to the ECM1 locus. Sequence analysis of the coding exons and splice junctions of the ECM1 gene revealed a novel homozygous mutation (c.616C > T) in exon 6, predicted to replace glutamine with stop codon (p.Q206X) at amino acid position 206.
\end{abstract}

Conclusions: The finding of a novel mutation in Pakistani family extends the body of evidence that supports the importance of ECM1 gene for the development of lipoid proteinosis.

Keywords: ECM1, genodermatoses, mutation, Pakistan

\section{Background}

Lipoid proteinosis (LP; MIM 247100) also known as Urbach-Wiethe disease or hyalinosis cutis et mucosae, was first reported by Urbach and Wiethe, in 1929 [1]. It is a rare genetic disease, which is inherited in an autosomal recessive fashion. The disease occurs worldwide but is more common in certain geographical areas such as the Northern Cape province of South Africa, including Namaqualand. Clinical heterogeneity is reported in LP [2], although it usually presents in early childhood with hoarseness, caused by infiltration of the laryngeal mucosa [3]. Skin lesions or pox-like scars usually appear simultaneously or shortly afterwards. Other characteristic findings include the arrangement of 'beaded' waxy papules, known as moniliform blepharosis, which may be present along the margins of both eyelids $[4,5]$.

\footnotetext{
* Correspondence: mnaeem@qau.edu.pk

${ }^{3}$ Department of Biotechnology, Quaid-i-Azam University, Islamabad-45320, Pakistan

Full list of author information is available at the end of the article
}

Histological and ultra structural examination has revealed the widespread deposition of hyaline-like material and disruption/reduplication of basement membrane around blood vessels and at the dermal-epidermal junction, mouth and upper respiratory tract, and other internal organs $[2,6]$. Overproduction of normally expressed non-collagenous protein in the hyaline material has also been reported [7]. Tongue is often firm and its mobility may be limited. Other symptoms may include thickening of frenulum, scarring, warty skin papules, nail dystrophy, dental anomalies and some neuropsychiatric symptoms [8,9]. Molecular genetic studies of LP linked the disorder to chromosome 1q21.1 [2]. The responsible gene was identified as ECM1, which encodes for the glycoprotein extracellular matrix protein 1 . To date, several mutations in the ECM1 gene have been reported in unrelated LP families from different geographical areas. In this study we report a novel nonsense mutation in a consanguineous Pakistani family affected with lipoid
Ciomed Central

() 2011 Nasir et al; licensee BioMed Central Ltd. This is an Open Access article distributed under the terms of the Creative Commons Attribution License (http://creativecommons.org/licenses/by/2.0), which permits unrestricted use, distribution, and reproduction in any medium, provided the original work is properly cited. 
proteinosis; and an update of $E C M 1$ gene mutation data base.

\section{Methods \\ Subjects}

A consanguineous Pakistani family with autosomal recessive LP was ascertained from Rawalpindi district. Two individuals (ages 15 and 23 years) in the family were affected with the disorder (Figure 1). Detailed clinical examination of all the family members, including affected individuals (IV-1, IV-2), their parents (III-1, III-2) and normal siblings (IV-3, IV-4, IV-5), was carried out by a dermatologist at local Leprosy Hospital. Before the start of the study, approval was obtained from the Quaid-iAzam University institutional review board. In addition, informed consent was obtained from the family members who participated in the study. Blood samples from patients, their parents and 3 unaffected siblings were collected and genomic DNA was extracted by the standard phenol-chloroform method. DNA samples from 100 ethnically matched unrelated normal Pakistani individuals were also collected as controls.

\section{Genotyping}

Genomic DNA from seven individuals of the family was genotyped using microsatellite markers tightly linked to the ECM1 gene. Polymorphic microsatellite markers were polymerase chain reaction (PCR) amplified. Each reaction was carried out in $10 \mu \mathrm{l}$ volume containing $1.5 \mathrm{mM} \mathrm{MgCl} 2,0.6 \mu \mathrm{M}$ of each primer, $0.2 \mathrm{mM}$ each dNTPs, $1 \mathrm{U}$ Taq DNA polymerase and $1 \times$ PCR buffer $\{16 \mathrm{mM}$ (NH4) 2SO4, 67mMTris-HCI (pH 8.8), and $0.01 \%$ of the nonionic detergent Tween-20\} (Bio-line, London, UK). Amplification was performed with an initial denaturation for $5 \mathrm{~min}$ at $94^{\circ} \mathrm{C}$, followed by 35 cycles of denaturation at $94^{\circ} \mathrm{C}$ for $45 \mathrm{sec}$, annealing at $55^{\circ} \mathrm{C}$ for $45 \mathrm{sec}$, extension at $72^{\circ} \mathrm{C}$ for $45 \mathrm{sec}$ and a final extension at $72^{\circ} \mathrm{C}$ for $10 \mathrm{~min}$. The PCR products were separated on $8 \%$ non-denaturing polyacrylamide gels stained with ethidium bromide and alleles were assigned by visual inspection.

\section{Mutation analysis}

For detection of mutation in the ECM1 gene, 8 sets of primers were used to amplify all coding exons and adjacent splice sites by PCR. PCR products were initially screened for mutations by single stranded conformational polymorphism (SSCP) analysis. For this, aliquots of $10 \mu \mathrm{l}$ of each PCR product was mixed with $10 \mu \mathrm{l}$ denaturing solution (95\% formamide, $20 \mathrm{mM}$ EDTA $\mathrm{pH}$ 8.0, $0.05 \%$ xylene-cyanole and $0.05 \%$ bromo phenol blue), heated for $7 \mathrm{~min}$ at $95^{\circ} \mathrm{C}$ in PxE thermal cycler (Hybaid, Basingstoke, U.K.) and chilled quickly on ice for $5 \mathrm{~min}$. Denatured DNA was subjected to $8 \%$ polyacrylamide gel electrophoresis $(20 \times 20 \times 0.1 \mathrm{~cm})$ containing $7 \%$ glycerol and $1 \times$ tris-borate EDTA $(\mathrm{TBE})$

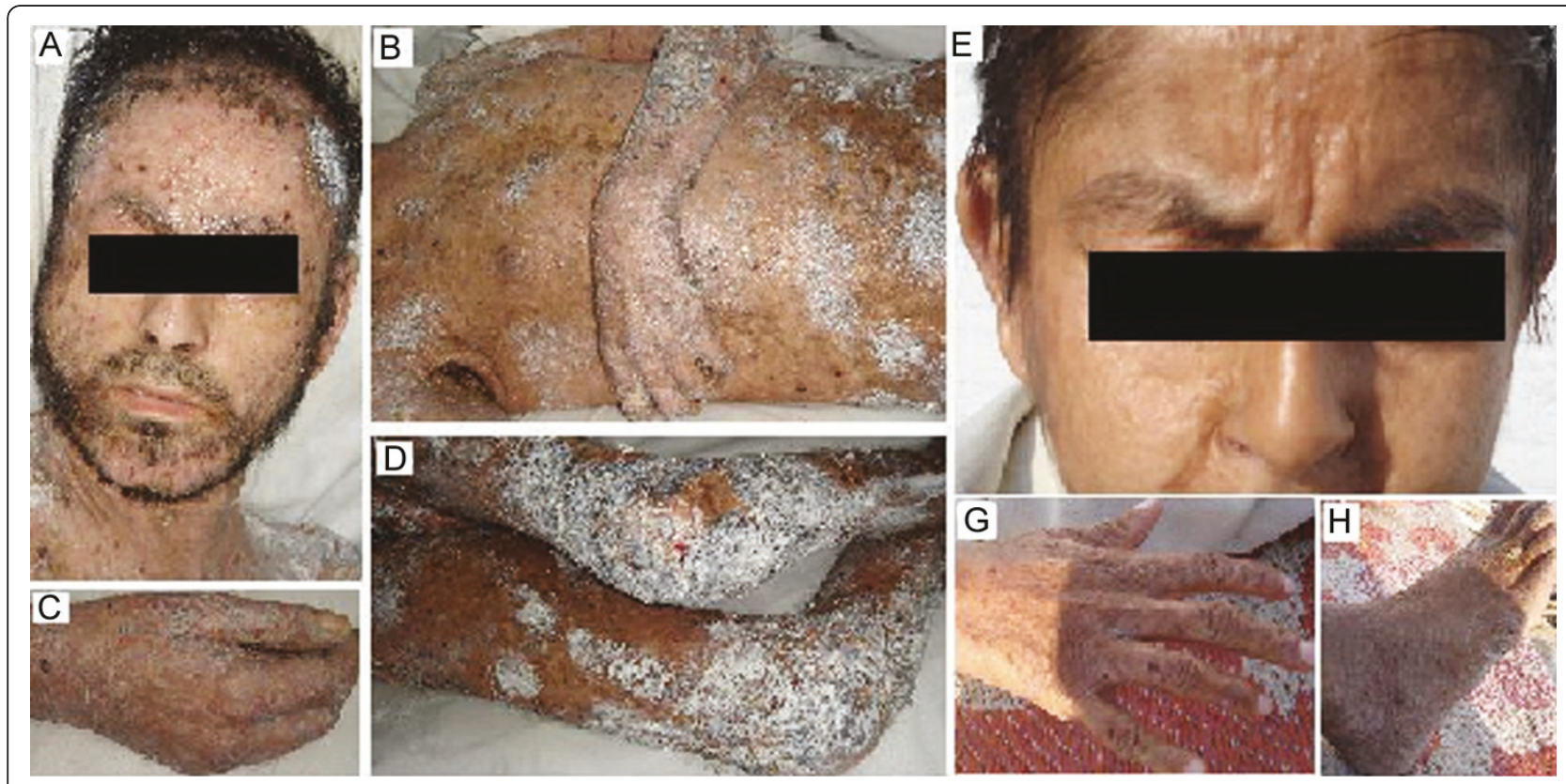

Figure 1 Clinical presentation of the lipoid proteinosis patients. (A) A 23 years old patient with yellow-white infiltrates and diffuse acneiform scars on the face; yellow discolouration of lips is also prominent; (B) Infiltrated skin of the trunk and upper extremities with numerous scars; (C, D, G, and H) Warty skin, thickening \& infiltration on the hands, legs, knees and foot. (E) A 15 years old patient with nodular or diffuse yellow waxy infiltrates located on the face; pseudo solar elastosis of the cheeks and forehead. 
buffer at constant 30W for 3.5-4.0 hrs. The gels were stained with ethidium bromide $(1 \mu \mathrm{g} / \mathrm{ml})$ in $1 \times \mathrm{TBE}$ buffer for about $5 \mathrm{~min}$ and visualized under UV transilluminator gel documentation system (Syngene, UK). The PCR products with mobility shift were then purified for DNA sequencing using commercially available QIAquick PCR Purification Kit (Qiagen, Crawley, U.K.). Direct sequencing was carried out by using Big Dye ${ }^{\circledR}$ Terminator v3.1 cycle sequencing kit in an ABI 3130 genetic analyzer (Applied Biosystems, Foster City, CA, U.S.A.).

\section{Results}

\section{Clinical details}

The affected individuals had hoarseness of voice, pseudosolar elastosis of the cheeks and forehead and waxy papules along the margins of eyelids. Progressive thickening and scarring of the skin and mucous membranes, hyperkeratosis with warty papules on the palms and dorsum of the hands, elbow and knee were also observed. Mobility of the tongue was limited with yellow discoloration of the lips. The clinical features of LP were identical in both patients; however, severity was varied, which may be due to difference in age as many of the clinical features of LP only manifest fully with time. Both the affected individuals showed initial symptoms during infancy. The heterozygous parents and siblings revealed no clinical signs and symptoms of LP upon detailed skin examination.

\section{Genotyping}

Genotyping of two affected and five normal individuals of the family (Figure 2A) was performed with microsatellite markers (D1S2222, D1S3466, D1S498, D1S2347, D1S2345) mapped in the region of ECM1 gene. The markers were fully informative, and the results revealed that the affected individuals were homozygous for the markers suggesting linkage to the ECM1 gene.

\section{Mutation analysis}

The SSCP analysis revealed mobility shift bands in PCR products of exon 6 of the ECM1 gene. Mutant allele was found to be co-segregating with the disease phenotype in the family. Both affected individuals (IV-1, IV-2) in the family were homozygous for the mutant allele, while their parents (III-1, III-2) and normal siblings (IV-3, IV-4, IV-5) were heterozygous.

Direct sequencing of PCR products amplified from the affected individuals revealed a homozygous $\mathrm{C}>\mathrm{T}$ transition at nucleotide position 616 (c.616C > T) in exon 6 of the ECM1 gene (Figure 2C). To see the effect of substitution on the coding sequence, the nucleotide sequence was analyzed with CLC Workbench 4.0.2 software. The C > T transition at nucleotide 616 changes the codon for glutamine at amino acid position 206 into a stop codon (p. Q206X), predicting premature termination of ECM1 with 205 amino acids instead of 540 amino acids of the normal ECM1 protein. The mutation was confirmed by bidirectional DNA sequencing. The parents and three normal individuals of the family were heterozygous for the mutation. To ensure that the mutation does not represent a neutral polymorphism in the Pakistani population, 100 ethnically matched healthy control individuals were screened for the mutation by PCR followed by direct sequencing. The mutation was not identified outside the family.

\section{Discussion}

The ECM1 gene comprises of 10 exons and encodes for the extracellular matrix protein 1 . There are four splice variants including ECM1a, ECM1b and ECM1c, encoding proteins of 540, 415 and 559 amino acids, respectively. The recently described fourth splice variant comprises transcription of $71 \mathrm{bp}$ at the 3' end of intron 1 and part of exon 2 to give a truncated 57 amino acid protein [10]. ECM1 is a negative regulator of endochondral bone formation, inhibiting alkaline phosphatase activity and mineralization [11]. It promotes angiogenesis, and shows over expression in certain malignancies. It interacts with a variety of extracellular and structural proteins, contributing to the maintenance of skin integrity and homeostasis [12-14]. The expression studies have demonstrated presence of ECM1a within basal keratinocytes and ECM1b in suprabasal cells, suggesting a role for ECM1 in terminal keratinocyte differentiation [15].

Forty six mutations in the ECM1 gene have been described so far in unrelated patients affected with lipoid proteinosis (Table 1). These include 19 insertions/deletions, 15 nonsense, 8 missense and 4 splice site mutations. Both homozygous and compound heterozygous genotypes have been reported. About half of all mutations (22 of 46) are located within exon 6 or 7 (including adjacent splice sites). Therefore, sequencing of these two exons has been suggested as the initial step in efficiently determining the molecular pathology in new cases of LP. Furthermore, as previously reviewed by Chan et al 2007, there is no clear paradigm for genotype phenotype correlation, considering the type and position of the ECM1 gene mutations reported so far. Most of the mutations in the ECM1 gene are specific to individual families and only few are recurrent. In the present study, we identified a novel nonsense mutation (Q206X) in exon 6 of the ECM1 gene in a consanguineous Pakistani family. Five ECM1 mutations have been previously reported in unrelated Pakistani LP families (Table 1) and to our knowledge there is no report of recurrent mutation. The Q206X mutation is predicted to result in the increased degradation of both full-length ECM1a and ECM1b transcripts due to nonsense mediated 


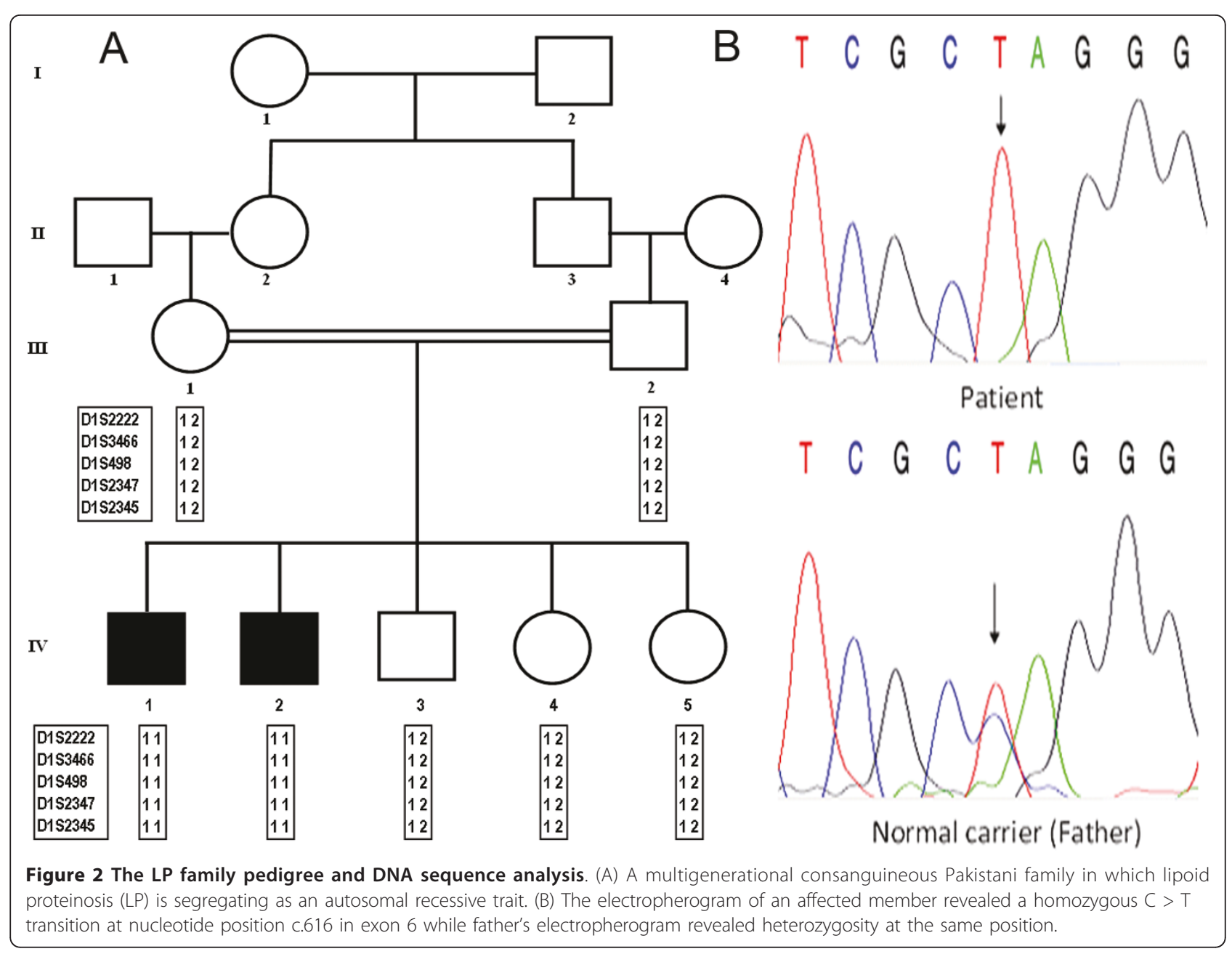

Table 1 Summary of the mutations in the ECM1 gene reported so far

\begin{tabular}{|c|c|c|c|c|c|}
\hline Position & $\begin{array}{l}\text { Sequence } \\
\text { change }\end{array}$ & $\begin{array}{l}\text { Mutation } \\
\text { type }\end{array}$ & $\begin{array}{l}\text { Predicted } \\
\text { protein change }\end{array}$ & Patient origin & Reference \\
\hline \multicolumn{6}{|c|}{ Genotype: homozygous } \\
\hline Intron 1 & IVS1+1G>C & Splice site & $\begin{array}{l}\text { Removal of the translation initiation } \\
\text { site }\end{array}$ & $\begin{array}{l}\text { Israeli Arab, } \\
\text { Kuwaiti, Egyptian }\end{array}$ & 10,17 \\
\hline Exon 2 & c.93G $>\mathrm{T}$ & Missense & p.R31S & Libyan & 19 \\
\hline Exon 2 & c.94 C>T & Nonsense & p.Q32X & Libyan, Indian & 17,19 \\
\hline Exon 3 & C.157 C>T & Nonsense & p.R53X & Japanese & 20,21 \\
\hline Exon 3 & c. 220 C>T & Nonsense & p.Q74X & Indian & 17 \\
\hline Exon 4 & c.243delG & Deletion & In-frame deletion of 61 amino acids & Thai & 20 \\
\hline Exon 5 & c.340 C>T & Nonsense & p.Q114X & Japanese & 17 \\
\hline Exon 6 & C.499 T>C & Missense & p.F167L & Polish & 22 \\
\hline Exon 6 & c.501insC & Insertion & Frame shift & Dutch, Belgian & 2,23 \\
\hline Exon 6 & c.507delT & Deletion & Frame shift & $\begin{array}{l}\text { Japanese, Thai, Indian, Canadian, Iranian, Turkish, } \\
\text { Pakistani, Chinese }\end{array}$ & $\begin{array}{l}17,20,23,24 \\
25,26\end{array}$ \\
\hline Exon 6 & c.541del3ins 16 & Indel & Frame shift & Brazilian & 27 \\
\hline Exon 6 & c.589 C>T & Nonsense & p.Q197X & Italian & 28 \\
\hline Exon 6 & C.629 T>C & Missense & p.L210P & French & 17 \\
\hline Exon 6 & c.658 T>G & Missense & p.C220G & Chinese & 29,30 \\
\hline Exon 7 & c.727 C>T & Nonsense & p.R243X & Belgian & 31 \\
\hline
\end{tabular}


Table 1 Summary of the mutations in the ECM1 gene reported so far (Continued)

\begin{tabular}{|c|c|c|c|c|c|}
\hline Exon 7 & c.735delTG & Deletion & Frame shift & Turkish & 20 \\
\hline Exon 7 & c.742 G>T & Nonsense & p.E248X & Indian & 32 \\
\hline Exon 7 & c.785delA & Deletion & Frame shift & Indian & 20 \\
\hline Exon 7 & $c .806 \mathrm{G}>\mathrm{A}$ & Missense & p.C269T & Saudi Arabian & 33 \\
\hline Exon 7 & $c .826 C>T$ & Nonsense & p.Q276X & South African & 2 \\
\hline Exon 7 & c.892delC & Deletion & Frame shift & Japanese & 20 \\
\hline Exon 7 & c. 1036 C>T & Nonsense & p.Q346X & Pakistani & 2 \\
\hline Exon 7 & c. $1077 \mathrm{G}>\mathrm{A}$ & Nonsense & p.W359X & British & 2,17 \\
\hline Exon 7 & c.1019delA & Deletion & Frame shift & Kuwaiti & 2 \\
\hline Intron 7 & IVS7+1G>A & Splice site & & Pakistani & 17 \\
\hline Exon 8 & c.1106 A>G & Missense & p.H369C & Indian & 17 \\
\hline Exon 8 & c.1190insC & Insertion & Frame shift & American & 20 \\
\hline Exon 8 & c.1209ins62 & Insertion & Frame shift & Pakistani & 34 \\
\hline Exon 8 & c. 1246 C>T & Nonsense & p.R416X & Indian & 17 \\
\hline Exon 8 & c.1253delC & Deletion & Frame shift & British & 17 \\
\hline Exon 8 & c.1300delAA & Deletion & Frame shift & Saudi Arabian & 17,33 \\
\hline Intron 8 & IVS8+1G>A & Splice site & & Pakistani & 17 \\
\hline $\begin{array}{l}\text { Intron } 8 \text { - } \\
\text { Intron } 10\end{array}$ & IVS8_IVS10del & Deletion & $\begin{array}{l}\text { Deleterious effect on protein structure } \\
\text { and function }\end{array}$ & Saudi Arabian & 2,33 \\
\hline Exon 10 & c.1393delA & Deletion & Frame shift & Israeli & 18 \\
\hline Exon 10 & c. 1426 C>T & Nonsense & p.R476X & Indian & 17 \\
\hline Exon 10 & c.1441 C>T & Nonsense & p.R481X & Indian & 17 \\
\hline \multicolumn{6}{|c|}{ Genotype: compound heterozygous } \\
\hline Exon 1 & $c .29 \mathrm{~T}>\mathrm{G}$ & Missense & p.V10G & Polish & 17 \\
\hline Intron 1 & IVS1+1G>A & Splice site & & & \\
\hline Exon 3 & c. $157 \mathrm{C}>\mathrm{T}$ & Nonsense & p.R53X & Spanish & 17 \\
\hline Exon 6 & c.603delTG & Deletion & Frame shift & & \\
\hline Exon 4 & c.240delTC & Deletion & Frame shift & German & 18 \\
\hline Exon 7 & c.1019delA & Deletion & Frame shift & & \\
\hline Exon 4 & c.283 C>T & Nonsense & p.Q95X & British & 17 \\
\hline Exon 10 & c.1432delA & Deletion & Frame shift & & \\
\hline Exon 6 & c. $480 \mathrm{G}>\mathrm{A}$ & Nonsense & p.W160X & Canadian & 20 \\
\hline Exon 6 & c. $499 \mathrm{~T}>\mathrm{A}$ & Missense & p.F167| & & \\
\hline Exon 6 & c.542insAA & Insertion & Frame shift & Italian & 20 \\
\hline Exon 7 & $c .727$ C>T & Nonsense & p.R243X & & \\
\hline Exon 6 & $\begin{array}{l}\text { c.543delTG/ } \\
\text { ins } 15\end{array}$ & Indel & Frame shift & Italian & 35 \\
\hline Exon 7 & c.727 C>T & Nonsense & p.R243X & & \\
\hline Exon 6 & c.658 T>G & Missense & p.C220G & Chinese & 36 \\
\hline Exon 10 & c. 1426 C>T & Nonsense & p.R476X & & \\
\hline Exon 7 & c.727 C>T & Nonsense & p.R243X & Italian & 17 \\
\hline Exon 7 & c.735delTG & Deletion & Frame shift & & \\
\hline
\end{tabular}

mRNA decay mechanism. Exceptionally, ECM1 transcripts might be expressed stably leading to production of truncated ECM1 protein. Although, functional consequences of the premature termination codon mutations must be established by northern blotting or quantitative reverse transcriptase PCR, previous reports have not suggested any difference in phenotype related to different mutation genotypes. Premature stop codons in the last exon lead to the presence of ECM1 truncated protein because the non sense mediated mRNA decay is dependent on an upstream exon-exon junction [16]. However, such patients did not show a different or milder phenotype in comparison with cases with more upstream mutations $[17,18]$.

\section{Conclusions}

We have identified a novel nonsense mutation in exon 6 of the ECM1 gene in a Pakistani family extending the mutation spectrum of the gene. The study extends the 
body of evidence that supports the role of ECM1 gene in the development of lipoid proteinosis. Identification of pathogenic mutations in the ECM1 gene should be helpful to improve genetic counseling and DNA based prenatal diagnosis.

\section{Acknowledgements}

We thank the family members for their invaluable cooperation. The research work was supported by Higher Education Commission of Pakistan.

\section{Author details}

'Institute of Biomedical and Genetic Engineering, GPO Box 2891, 24-Mauve Area, G-9/1, Islamabad, Pakistan. ${ }^{2}$ Leprosy Hospital, Rawalpindi, Pakistan. ${ }^{3}$ Department of Biotechnology, Quaid-i-Azam University, Islamabad-45320, Pakistan.

\section{Authors' contributions}

$M N^{1}$ performed experimental work, AL performed clinical study of the family, MA participated in experimental work, RQ updated mutation database and participated in manuscript preparation, $\mathrm{MN}^{2}$ analyzed data and prepared manuscript, AH designed research plan and analyzed data. All authors read and approved the final manuscript.

\section{Competing interests}

The authors declare that they have no competing interests.

Received: 17 May 2011 Accepted: 26 July 2011 Published: 26 July 2011

\section{References}

1. Urbach E, Wieth C: Lipoidosis cutis et mucosae. Virchows Arch 1929, 273:285-319.

2. Hamada T, McLean WHI, Ramsay M: Lipoid proteinosis maps to 1q21 and is caused by mutations in the extracellular matrix protein 1gene (ECM1). Hum Mol Genet 2002, 11:833-840.

3. Touart DM, Sau P: Cutaneous deposition diseases. Part I. J Am Acad Dermatol 1998, 39:149-171.

4. Dinakaran S, Desai SP, Palmer IR: Lipoid proteinosis: clinical features and electron microscopic study. Eye 2001, 15:666-668.

5. Black MM: Lipoid proteinosis. In RookWilkinson/Ebling Textbook of Dermatology.. 6 edition. Edited by: Champion RH, Burton JL, Burns DA, Breathnach SM. Oxford: Blackwell Science; 1998:2640-2641.

6. Heyl T: Lipoid proteinosis I: the clinical picture. Br J Dermatol 1963, 75:465-72.

7. Fleischmajer R, Krieg T, Dziadek M: Ultrastructure and composition of connective tissue in hyalinosis cutis et mucosae skin. $J$ Invest Dermatol 1984, 82:252-258.

8. Hofer P: Urbach-Wiethe disease (lipoglycoproteinosis; lipoid proteinosis; hyalinosis cutis et mucosae. A review in Acta Derm Venereol Suppl (Stockh.) 1973, 53:1-52.

9. Newton FH, Rosenberg RN, Lampert PW: Neurological involvement in Urbach- Wiethe's disease (lipoid proteinosis): a clinical, ultra structural and chemical study. Neurology 1971, 21:1205-1213.

10. Horev H, Potikha T, Ayalon V: A novel splice-site mutation in ECM-1 gene in a consanguineous family with lipoid proteinosis. Exp Dermatol 2005, 14:891-897.

11. Deckers MM, Smits P, Karperien M: Recombinant human extracellular matrix protein 1 inhibit alkaline phosphatase activity and mineralization of mouse embryonic metatarsals in vitro. Bone 2001, 28:14-20.

12. Han Z, Ni J, Smits P: Extracellular matrix protein 1 (ECM1) has angiogenic properties and is expressed by breast tumor cells. FASEB J 2001, 15:988-994.

13. Le Naour F, Hohenkirk L, Grolleau A, Misek DE, Lescure P, Geiger JD, Hanash S, Beretta L: Profiling changes in gene expression during differentiation and maturation of monocytederived dendritic cells using both oligonucleotide microarrays and proteomics. J Biol Chem 2001, 276:17920-17931.

14. Rickman D, Bobek M, Misek D: Distinctive molecular profiles of highgrade and low-grade glinomas based on oligonucleotide microarray analysis. Cancer Res 2001, 61:6885-6891.
15. Smits P, Poumay $Y$, Karperien M: Differentiation-dependent alternative splicing and expression of the extracellular matrix protein 1 gene in human keratinocytes. J Invest Dermatol 2000, 114:718-724.

16. Maquat LE: Nonsense-mediated mRNA decay in mammals. J Cell Sci 2005, 118:1773-6

17. Chan I, Liu L, Hamada T, Sethuraman G, McGrath JA: The molecular basis of lipoid proteinosis: mutations in extracellular matrix protein 1. Experimental Dermatology 2007, 16:881-890.

18. Horev L, Wollina U, Potikha T, Hafner A, Ingber A, Liu L, McGrath JA, Zlotogorski A: Lipoid proteinosis: identification of two novel mutations in the human ECM-1 gene and lack of genotypephenotype correlation. Acta Derm Venereol 2009, 89:528-529.

19. Chan I, El-Zurghany A, Zendah B: Molecular basis of lipoid proteinosis in a Libyan family. Clin Exp Dermatol 2003, 28:545-548.

20. Hamada T, Wessagowit $V$, South AP: Extracellular matrix protein 1 gene (ECM1) mutations in lipoid proteinosis and genotype-phenotype correlation. J Invest Dermatol 2003, 120:345-350.

21. Akoglu G, Karaduman A, Ergin S, Erki G, Gokoz O, Unal OF, Hamada T: Clinical and histopathological response to acitretin therapy in lipoid proteinosis. Journal of Dermatological Treatment 2010.

22. Kowalewski C, Kozlowska A, Chan I: Three-dimensional imaging reveals major changes in skin microvasculature in lipoid proteinosis and lichen sclerosus. J Dermatol Sci 2005, 38:215-224.

23. Desmet S, Devos SA, Chan I: Clinical and molecular abnormalities in lipoid proteinosis. Eur J Dermatol 2005, 15:344-346.

24. Chan I, Bingewar G, Patil K, Nayak C, Wadhwa SL, McGrath JA: An Indian child with lipoid proteinosis resulting from a recurrent frameshift mutation (507delT) in the extracellular matrix protein 1 (ECM1) gene. $\mathrm{Br}$ J Dermatol 2004, 151:726-727.

25. Poyrazolu S, Günöz H, Darendeliler F: Severe Short Stature: an unusual finding in lipoid proteinosis. J Clin Res Ped Endo 2008, 1:97-101.

26. Samdani AJ, Azhar A, Shahid SM, Nawab SN, Shaikh R, Qader SA, Mansoor Q, Khoso BK, Ismail M: Homozygous frame shift mutation in ECM1 gene in two siblings with lipoid proteinosis. Journal of Dermatological Case Reports 2010, 4.

27. Teive HA, Pereira ER, Zavala JA: Generalized dystonic and striatal calcifications with lipoid proteinosis. Neurology 2004, 63:2168-2169.

28. Lupo I, Cefalu AB, Bongiomo MR: A novel mutation of the extracellular matrix protein 1 gene (ECM1) in a patient with lipoid proteinosis (Urbach-Wiethe disease) from Sicily. Br J Dermatol 2005, 153:1019-1022.

29. Han B, Zhang X, Liu Q, Chen X, Zhu X: Homozygous missense mutation in the ECM1 gene in Chinese siblings with lipoid proteinosis. Acta Derm Venereol 2007, 87:387-389.

30. Kautz O, Müller S, Braun-Falco M, Nashan D: A Chinese family with lipoid proteinosis resulting from a homozygous missense mutation in the extracellular matrix protein 1 gene. Journal of European Academy of Dermatology and Venereology 2009, 23:1327-1349.

31. Claeys KG, Claes LRF, Goethem JWM, Sercu S, Merregaert J, Lambert J, Marck EAV, Parizel PM, Jonghe PD: Epilepsy and migraine in a patient with Urbach-Wiethe disease. Seizure 2007, 16:465-468.

32. Chan I, Sethuraman G, Sharma VK, Bruning E, Hamada T, McGrath JA: Molecular basis of lipoid proteinosis in two Indian siblings. J Dermatol 2004, 31:764-766.

33. Salih MA, Abu-Amero KK, Alrasheed S, Alorainy IA, Liu L, McGrath JA, Maldergem LV, Al-Fakey YH, AlSuhaibani AH, Oystreck DT, Bosley TM: Molecular and neurological characterizations of three Saudi families with lipoid proteinosis. BMC Medical Genetics 2011, 12:1-6.

34. Nasir M, Latif A, Ajmal M, Ismail M, Hameed A: A novel homozygous 62-bp insertion in ECM1 causes lipoid proteinosis in a multigeneration Pakistani family. British Journal of Dermatology 2009, 161:688-690.

35. Di Giandomenico S, Masi R, Cassandrini D: Lipoid proteinosis: case report and review of the literature. Acta Otorhinolaryngol Ital 2006, 26:162-167.

36. Wang CY, Zhang PZ, Zhang FR, Liu J, Tian HQ, Yu L: New compound heterozygous mutations in a Chinese family with lipoid proteinosis. $\mathrm{Br} J$ Dermatol 2006, 155:470-472.

doi:10.1186/1746-1596-6-69

Cite this article as: Nasir et al:: Molecular analysis of lipoid proteinosis: identification of a novel nonsense mutation in the ECM1 gene in a Pakistani family. Diagnostic Pathology 2011 6:69. 